University of Texas Rio Grande Valley

ScholarWorks @ UTRGV

$4-2-2020$

\title{
The Security Apparatus, Federal Magistrate Courts, and Detention Centers as Simulacra: The Effects of Trump's Zero Tolerance Policy on Migrants and Refugees in the Rio Grande Valley
}

\section{Terence Garrett}

The University of Texas Rio Grande Valley, terence.garrett@utrgv.edu

Follow this and additional works at: https://scholarworks.utrgv.edu/pol_fac

Part of the Anthropology Commons, Political Science Commons, and the Sociology Commons

\section{Recommended Citation}

Garrett, T.M. (2020), The Security Apparatus, Federal Magistrate Courts, and Detention Centers as Simulacra: The Effects of Trump's Zero Tolerance Policy on Migrants and Refugees in the Rio Grande Valley. Politics Policy, 48: 372-395. doi:10.1111/polp.12348

This Article is brought to you for free and open access by the College of Liberal Arts at ScholarWorks @ UTRGV. It has been accepted for inclusion in Political Science Faculty Publications and Presentations by an authorized administrator of ScholarWorks @ UTRGV. For more information, please contact justin.white@utrgv.edu, william.flores01@utrgv.edu. 


\title{
The Security Apparatus, Federal Magistrate Courts, and Detention Centers as Simulacra: The Effects of Trump's Zero Tolerance Policy on Migrants and Refugees in the Rio Grande Valley
}

\author{
Terence Michael Garrett, PhD
}

The University of Texas, Rio Grande Valley

Trump's DHS implemented the Zero Tolerance policy from April 6 to June 24, 2018. Refugees, prevented from crossing the midpoints of bridges by Customs and Border Protection agents, crossed the Rio Grande to ask for asylum, were denied, and forced to cross at places deemed illegal by law. This resulted in misdemeanor violations for unlawful entry and fleeing immigration checkpoints. The policy initiative centered on the separation of children from their migrant parents-refugees fleeing from the northern triangle countries: El Salvador, Honduras, and Guatemala. Adult migrants were sent to prisons and holding facilities, brought before a magistrate to plead guilty, and were deported while their children were placed in government-funded privately-owned detention centers. Migrants contend with a security apparatus comprised of border walls, zones of surveillance, agents, and paramilitary troops. This article analyzes the United States (in)security system using Baudrillard's concept of simulacrum supplemented by Foucault's dispositif and Agamben's apparatuses.

Keywords: Simulacra, Apparatus, Dispositif, Zero Tolerance Policy, Homeland Security, MexicoU.S. Border, Refugees, Homo Sacer, Agamben, Baudrillard, Foucault, Immigration, Migration, State of Exception, Security, Terrorism, War, Political Issues.

Related Articles: Silverman, Stephanie J. 2012. "Regrettable but Necessary?” A Historical and Theoretical Study of the Rise of the U.K. Immigration Detention Estate and Its Opposition." Politics \& Policy 40 (6): 1131-1157. https://doi.org/10.1111/j.1747-1346.2012.00393.x

Byrne, Jennifer and Gregory C. Dixon. 2013. "Reevaluating American Attitudes toward Immigrants in the Twenty-First Century: The Role of a Multicreedal National Identity." Politics \& Policy 41 (1): 83-116. https://doi.org/10.1111/polp.12002

Duman, Yoav H. 2014. "Reducing the Fog? Immigrant Regularization and the State." Politics \& Policy 42 (2): 187-220. https://doi.org/10.1111/polp.12065

El aparato de seguridad, los tribunales de magistrados federales y los centros de detención como simulacros: los efectos de la política de tolerancia cero de Trump en los migrantes y refugiados en el Valle del Río Grande

El DHS de Trump implementó la política de Tolerancia Cero del 6 de abril al 24 de junio de 2018. Los refugiados, que los agentes de Aduanas y Protección Fronteriza impidieron que cruzaran los puntos medios de los puentes, cruzaron el Río Bravo para pedir asilo, fueron denegados y fueron obligados a cruzar en

Acknowledgements: The authors would like to thank the anonymous referees at Politics \& Policy whose comments helped to improve the final quality of the text. 
los lugares considerados ilegal por ley. Estas acciones resultaron en infracciones menores por entrada ilegal y huir de los puntos de control de inmigración. La iniciativa política se centró en la separación de los niños de sus padres migrantes, refugiados que huían de los países del triángulo norte: El Salvador, Honduras y Guatemala. Los inmigrantes adultos fueron enviados a cárceles y centros de detención, llevados ante un magistrado para declararse culpable y deportados mientras sus hijos fueron colocados en centros de detención privados financiados por el gobierno. Los migrantes se enfrentan a un aparato de seguridad compuesto por muros fronterizos, zonas de vigilancia, agentes y tropas paramilitares. Este artículo analiza el sistema de seguridad de EE. UU. (In) utilizando el concepto de simulacro de Baudrillard complementado por el dispositivo de Foucault y los aparatos de Agamben.

Palabras clave: Simulacros, Aparatos, Dispositivos, Política de tolerancia cero, Seguridad nacional, Frontera México-Estados Unidos, Refugiados, Migrantes.

\section{安全部署、联邦地方法院和拘留中心所扮演的拟像: 特朗普的零容忍政策对里奥格兰德山谷地区 的移民和难民所产生的效果}

特朗普政府的国土安全部在2018年4月6日至6月24日期间实行了 “零容忍” 政策。海关与边境保护 官员防止难民通过桥梁的中间点, 后者继而穿过里奥格兰德山谷以寻求庇护, 但却遭到拒绝, 并 被强制穿过非法地区。这一系列行为导致了非法入境和逃离移民检查点等轻度犯罪。该政策倡议 的重点是将儿童与其移民父母分离, 后者作为难民逃离北部三个国家: 萨尔瓦多、洪都拉斯和危 地马拉。成年移民被送往监狱和拘留所, 他们被带到地方法院认罪, 并被驱逐处境, 儿童则被安 置在由政府出资的私有拘留中心。移民挣扎在一个由边境墙、监控区、官员和准军事军队组成的 安全部署区。本文使用以鲍德里亚的拟像概念为主, 福柯的dispositif机制、阿甘本的部署 (apparatus) 理论为辅, 分析了美国（不）安全体系。

关键词：拟像, 部署（Apparatus）, Dispositif，零容忍政策，国土安全，墨西哥-美国边界，难民， 移民。

The approach for this critical policy analysis of U.S. border security and the Trump administration is based on the works of Jean Baudrillard (2006), Michel Foucault (1970, 1980, 2008), and Giorgio Agamben (1995, 2005, 2009). In terms of their respective philosophical backgrounds germane specifically to the analysis of public policy_particularly the topic President Trump's implementation of the Zero Tolerance policy—-these scholars' theoretical insights shed some light in terms of the power of the state to circumvent the laws to justify policy ends at odds with legal and constitutional parameters previously adhered to by previous administrations. Baudrillard's concept of simulacrum is utilized to illustrate the problem of perception of symbols, 
or images, manipulated and managed by government decision makers. Important here is the symbolism of the border wall and accompanying accoutrements-border security personnel, surveillance devices, etc.- designed ostensibly to provide protection along the frontier region, specifically the Mexico-U.S. border. In previous work (Garrett and Storbeck 2011, Garrett 2018), the border wall was analyzed as a simulacrum. Simulacra are images, or symbols, that change meaning temporally and spatially. The simulacra of the border wall and the September 11, 2001 (hereafter "9/11") terrorist attacks (Noe 2002) previously were depicted thusly.

Figure 1. 9/11 and the Border Wall Become Hyperreal, Simulacra

\begin{tabular}{|c|}
\hline It [the image] is the reflection of a profound reality; (the image is a good appearance) \\
\hline The border fence is the image of homeland security. \\
\hline It masks and denatures a profound reality; (it is an evil appearance) \\
\hline $\begin{array}{l}\text { The border wall is the image of oppression: loss of land, detrimental to society and } \\
\text { commerce-leading to despair and fear. }\end{array}$ \\
\hline It masks the absence of a profound reality; (it plays at being an appearance) \\
\hline $\begin{array}{l}\text { The border fence/wall gives the impression of a sense of security at the expense of those } \\
\text { victimized by its presence in the lower Rio Grande Valley. }\end{array}$ \\
\hline 4. It has no relation to any reality whatsoever; (it is no longer of the order of appearance) \\
\hline $\begin{array}{l}\text { The border fence in its 18-foot-high physical construction does not lead to real security (if it } \\
\text { is at all completely possible)_agents on the ground, electronic surveillance methods, better } \\
\text { international immigration and national security policies are proven more effective [leading } \\
\text { to:] }\end{array}$ \\
\hline It is its own pure simulacrum \\
\hline $\begin{array}{l}\text { The simulacrum or "hyperreal" becomes real. } 9 / 11 \text { (itself having become a simulacrum) } \\
\text { makes other hyperreal actions possible, such as the border fence. The proposed border fence } \\
\text { becomes a manifestation of "security" based on the fears of another " } 9 / 11 \text { " by placing a } \\
\text { physical structure to impede or stop illegal immigration/terrorism; in reality, it represents a } \\
\text { porous and temporary barrier to delay crossing into the United States. }\end{array}$ \\
\hline
\end{tabular}

Source: (Originally based on Figure 2, Garrett and Storbeck 2011). Adapted by the authors from Baudrillard 2006; Noe 2002).

In terms of understanding the present ramifications of border security policy-border infrastructure, surveillance, and personnel—Baudrillard's simulacrum concept will be expanded 
to include the security apparatus (Agamben 2009), or dispositif (Foucault 2008), and going beyond 9/11 and the border wall project of 2006-09. The security apparatus is the imbrication of infrastructure (border walls), surveillance (the panopticon of aerial drones, tethered aerostats, sensors, cameras, etc.), and boots on the ground (Customs and Border Protection personnel, National Guard and active duty military troops). In essence, the security apparatus addressed here is the manifestation of the current U.S. government's attempts to exclude undocumented border crossers - or the homo sacer — from entering through the Mexico-U.S. border (Agamben 1995; Garrett and Storbeck 2011). In conducting an evaluation of border security, it is critically important to understand interpretations of people advocating for, and affected by, the implementation of the policy through raw political power, especially when the policy is at odds with the laws and treaties of the government of the United States. These added dimensions will improve the overall analysis of border security policy and its implications for governance in the United States.

The subsequent sections address the security apparatus in the following manner. First, there is conceptual confusion on behalf of policy makers surrounding what the border wall and border security is and how it is supposed to be implemented as public policy. Various interpretations are examined by analyzing public statements and stories given by elected and bureaucratic U.S. government officials responsible for border wall infrastructure and security. This narrative methodology provides insights into implementation and evaluation as to where the policy makers stand with regard to border security and whether their public statements are compatible with the law or extralegal in conception. Second, there is a discussion and elaboration of theories pertaining to simulacra and the security apparatus concepts and how they are applied to Trump's Zero Tolerance policy and his declared "state of emergency" used to justify the separation of families. Third, there is an initial discussion of the security apparatus as it pertains to affecting citizens and 
migrants in the United States through the implementation of border zones and the set aside of civil liberties protections such as the right to privacy and legal due process. Fourth, the Zero Tolerance policy is presented as a strategy in which migrant and refugee children are separated from their parents in order to prevent undocumented migration across the border with Mexico into the United States with the use of detention centers. The mechanics are laid out explicitly especially as the policy pertains to refugees and migrants crossing the border into Texas, with special emphasis in the lower Rio Grande Valley. Customs and Border Protection (CBP) tactics, U.S. Federal Courts dealing with migration matters, government agencies, and government contractors are analyzed for their various roles played in the implementation of Trump's Zero Tolerance policy. The next section provides an analysis of the combination of border wall architecture types as well as U.S. federal troop involvement in the border security apparatus. The addition of concertina wire promoted as a tactic of intimidation is examined in context of adverse effects on border dwellers and migrants. Finally, the policy ramifications of the simulacra of border security (1) the increased militarization - infrastructure, surveillance technology, and increased numbers of border agents and military personnel; (2) partisan differences and policy confusion; and, (3) political conflictare analyzed in the context of what the security apparatus means with regard to a movement away from representative democracy toward possible authoritarianism.

\section{Border Wall/Border Security Policy Confusion}

The (U.S. Senate minority) leader was confused.

Earlier this year, U.S. Rep. Henry Cuellar, D-Laredo, was dining at an Austin restaurant when he surprisingly ran into a powerful friend.

"Hey Henry, I have been meaning to talk to you," Senate Minority Leader Chuck Schumer said. "Did I hear you support the border wall in South Texas?"

"Oh no, senator," Cuellar said. "That is not true."

Cuellar then realized what Schumer meant.

"Oh," Cuellar said. "Do you mean the levee wall?"

"What is the difference?" Schumer said. (Ferman and Zazueta-Castro 2017) 
"A wall is an immorality - it is not who we are as a nation," Speaker Nancy Pelosi said on Thursday. "This is not a wall between Mexico and the United States that the president is creating here; it is a wall between reality and his constituents, his supporters." (Hirschfeld Davis and Baker 2019)

Nancy just said she "just does not understand why?" Very simply, without a Wall it all does not work. Our Country has a chance to greatly reduce Crime, Human Trafficking, Gangs and Drugs. Should have been done for decades. We will not Cave!-Donald J. Trump (8:16 AM - January 24, 2019 Twitter)

The discussion in 2017 between Senator Schumer and Congressman Cuellar illustrates the problem of defining the border "fence" or "wall" along the Southwest border between Mexico and the United States. Additionally, the conversation encapsulates the representation of the border security apparatus; the wall, federal bureaucratic agencies such as the U.S. Border Patrol (BP), Customs and Border Protection (CBP), U.S. Immigration and Customs Enforcement (ICE) within the Department of Homeland Security (DHS), and the judicial magistrates/federal court system established to deal with migration policy. The Speaker of the U.S. House of Representatives, Nancy Pelosi, notes that the wall symbolizes an immorality and is used to separate the president and his supporters from the rest of the United States. Conversely, President Trump promotes the wall to his Twitter followers as a solution for stopping the ills of crime and creating a zone of safety and security at the border-while simultaneously pressuring Congress to give him \$5.7 billion in the FY 2019 budget for the wall. Trump has declared a state of emergency as a result of his frustration with Congress.

We are talking about an invasion of our country with drugs, with human traffickers, with all types of criminals and gangs," he said. [Trump] used the word "invasion" seven times. He later said the emergency declaration was not urgent but rather expedient, as it would help him build a wall more quickly than Congress would allow. "I did not need to do this, but I would rather do it much faster. (Paletta et al. 2019).

And in a response to a reporter's question as to the necessity to build a wall under a declaration of a state of emergency, Trump stated: 
I could do the wall over a longer period of time, I did not need to do this, but I would rather do it much faster-and I do not have to do it for the election; I have already done a lot of the wall for the 2020 election. And the only reason we are up here talking about this is because of the election, because they want to try and win an election which it looks like they are not going to be able to do... And this is one of the ways they think they can possibly win is by obstruction and a lot of other nonsense. And I think that I just want to get it done faster, that is all (Blake 2019).

Solutions to border security other than physical barriers are not considered by Trump whose primary campaign was on the single issue of building his "big, fat, beautiful wall," whether it is effective as a deterrent or not for migrants and terrorists (Finnegan 2016). For example, a fiber optic cable technology could be employed, utilizing light and sound to detect border activity from San Diego, California to Brownsville, Texas, alerting CBP and BP agents at a fraction of the cost of various border wall proposals as "fiber-optic technology is already advanced enough to work across most of the US-Mexico border, nearly 10 times less expensive than a wall, and is ready to be deployed immediately" (Mark 2019). One of the problems of building the wall occurs in Texas, where up to 4,900 tracts of private property are within 500 feet of the Rio Grande, causing costly eminent domain issues engendered by the REAL ID Act of 2005 and the Secure Fence Act of 2006 (Ryman et al. 2017).

Critics of Trump's wall include Gil Kerikowske, former CBP Commissioner under President Obama, who said the border wall is "a waste of time and money" (Ross, Epstein, and Blake 2017). Similarly, former ICE Director Sarah Saldaña stated, "The true threats are those persons who come to do harm to our country, and that is quite frankly a very small number compared to the number of people who seek entry. This is why the wall that is being proposed, enforcement-wise, makes so little sense" (Mark 2019). Also, according to the former ICE Director, the wall does not stop violent criminals and drug trafficking organizations who ship their wares illegally through legal ports of entry as "in the first 11 months of the fiscal year $2018,90 \%$ of heroin, $88 \%$ of cocaine, $87 \%$ of methamphetamine, and $80 \%$ of fentanyl that U.S. authorities 
seized" at those locations (Mark 2019). Brown (2010, 125-6) explains that "where demand pulls the supply of labor or contraband and where state expansion and/or occupation is at stake, walls produce borders as permanent zones of violent conflict and incite sophisticated and dangerous underground industries, expand the size and expense of the problems they would solve, and aggravate hostilities on both sides" of the border. Additionally, Brown notes the "political, security, and economic effects of globalization...do not exhaust the elements animating contemporary First World constructions of a figure of alien enmity" (Brown 2010, 128). The border wall is effectively a social construction (Berger and Luckmann 1980; Schutz 1967) that in U.S. domestic politics pits the current president of the United States and his "Make America Great Again"- hat-wearing followers against a Democratic-led House of Representatives, civil rights groups, and a few former leaders of CBP and ICE who served under the previous president.

\section{Baudrillard's Simulacra, Foucault's Dispositif and Agamben's Apparatus in the Context of the State of Exception}

Baudrillard's (2006) concept of simulacra was previously used to analyze the wall on the Mexico-U.S. border by Garrett and Storbeck (2011) and Garrett (2018). Essentially, simulacra are images that have multiple interpretive meanings to different people, or images, going through successive phases spatially and temporally — while viewing or encountering the same object or thing. With the example of the border wall as a simulacrum (see also Figure 1 above), the hyperreality of it, the thing, may be good (representing an image of security; e.g., to policy makers and the public away from the wall in Washington D.C. far from the border), or evil (masking what it is as good, but the reality is that it represents insecurity; e.g., to border dwellers who lose property, have livelihood destroyed due to the destruction of the environment, etc.), and ultimately having no relation to reality whatsoever as a pure simulacrum (e.g., the wall does not keep out 
determined border crossers who cross an 18-foot high bollard structure with handmade 19-foot ladders in 30 seconds, or tunnel under, or fly drones with drugs over the wall, etc.) Garrett and Storbeck $(2011,535)$ state “The...border fence becomes a manifestation of 'security' based on the fears of another ' $9 / 11$ ' by placing a physical structure to impede or stop illegal immigration/terrorism; in reality, it represents a porous and temporary barrier to delay crossing into the United States.” The extension of the border wall simulacrum persists to the present.

With President Trump, the building and promotion of the border wall simulacrum continues. Mexico was supposed to pay for extending a big, beautiful wall from sea to shining sea - presumably from the Pacific Ocean near San Diego, California to Boca Chica near Brownsville, Texas where the Rio Grande flows into the Gulf of Mexico. Since the U.S. Congress has not given Trump what he wants in terms of border wall funding for the first two fiscal years of the federal budget, the simulacrum is repeated - as walls do not realistically hinder determined border crossers, whether they be migrants, refugees, or drug and human smugglers - and is nevertheless represented as an image of security to Trump's partisans even though it is clearly ineffective to make the public more secure. From 2014 to the present, migrants and refugees with children seek out the border wall when crossing the Rio Grande, for example, as a marker to walk toward and wait to be apprehended because it is a symbol (or image) of the Border Patrol—where they may be - so they may turn themselves in to make asylum claims. The border wall in the United States is on American territory and once a migrant or refugee takes one step inside the United States, they are legally allowed to make an asylum claim. Because of Trump's "Zero Tolerance" policy (more on this shortly), Customs and Border Protection agents stop migrants and refugees, for example, from stepping across the marker depicting the Mexico-U.S. border on bridges over the Rio Grande. Using Baudrillard's concept and updating the analysis of Garrett and 
Storbeck (2011), to migrants and refugees the border wall represents a simulacrum for safety and asylum.

The rest of the tripartite security apparatus (Garrett 2018) besides the border wall on the southern border with Mexico is comprised of the DHS agencies (e.g., the aforementioned CBP and BP) and border surveillance (e.g., motion sensors, radars, Tethered Aerostat Radar Systems, drones, aircraft, etc.). All three are used as key elements for the DHS security apparatus. The conceptual meaning of apparatus also has analytical meaning for understanding governance-and in this case, security of the state.

The concepts of dispositif and apparatus are critical to understanding problems of liberal democratic states intruding into the right to be secure at the expense of constitutionally given liberties. The specter of resistance to the state (in this case, the state security apparatus) is addressed by Agamben and Foucault (Frost 2019), has important implications for policy analysis regarding actions of the state, and is especially germane to border security. Foucault notes in The Birth of Biopolitics $(2008,64-5)$ that liberalism suffers through crises of the dispositif, or the general apparatus of governmentality, whereby "liberalism must produce freedom, but this very act entails the establishment of limitations, controls, forms of coercion, and obligations relying on threats" as "the problem of security is the protection of the collective interest against individual interests." The problem of the dispositif, including liberalism, is further explored and expanded by Agamben $(2009,14)$ in his conception of the apparatus as "literally anything that has in some way the capacity to capture, orient, determine, intercept, model, or secure the gestures, behaviors, opinions, or discourses of living beings." Agamben further explains that "we have then two great classes: living beings (or substances) and apparatuses...[and another] third class, subjects...[living with] the relentless fight between living beings and apparatuses." Liberalism is today the extreme phase 
of capitalist development "in which we live as a massive accumulation and proliferation of apparatuses...that today there is not even a single instant in which the life of individuals is not modeled, contaminated, or controlled by some apparatus" (Agamben 2009, 15).

The security apparatus of the United States is in full display and affecting those subject to its provisions - denial of constitutional protections and international law due to the current state of exception (Agamben 2005) now extended well beyond the imposition of the REAL ID Act of 2005, and the Secure Fence Act of 2006 relevant to the discourse of national and border security in the United States. Andreas $(2009,9)$ recognizes that the "logic of police escalation"- the security apparatus along the border-is due to a perceived loss of control "neglects its deeper roots and symbolic function" by U.S. border enforcement as practiced along the southern border and U.S. border law enforcement efforts have "never been a particularly effective or efficient deterrent against drugs and illegal immigrants." This tradition of border enforcement continues through to the present day and comes at the cost of the gradual usurpation of civil rights and liberties particularly of border zone dwellers and, of course, migrants and refugees.

In terms of a new strategy to thwart migrants from Central America circa April 6 to June 20, 2018, President Trump officially conducted his "Zero Tolerance" policy of separating children from their parents at the Mexico-U.S. border and allegedly put an end to the policy when pressured by human rights and civil liberties groups as well as the media (Garrett 2018)—despite the evidence that family separation continues as we will see below. Trump's declaration of a state of emergency to build the border wall based on "caravans" of migrants and refugees coming from mostly Central America is another extension of the pattern of continued expansion involving the permanent "state of siege" used as an executive rationale to suspend the normal division of constitutional powers and republican laws. Congress may attempt to veto the declaration, but 
would need 55 members of Trump's Republican party to vote with the majority Democrats and

have the U.S. Senate follow suit—both of which are highly unlikely (Edgerton, Wasson, and Litvan 2019). Trump's declaration may yet hold unless enough Republican members of Congress vote against it. Additionally, former state department secretaries and other former high-ranking U.S. government national and homeland security officials — 58 in total—have signed a bipartisan Joint Declaration of Former United States Government Officals after Trump's declaration of a state of emergency in February 2019 stating their collective opposition as follows:

1. [We, the undersigned, declare as follows]...

2. On February 15, 2019, the President declared a "national emergency" for the purpose of diverting appropriated funds from previously designated uses to build a wall along the southern border. We are aware of no emergency that remotely justifies such a step...

3. Illegal border crossings are near forty-year lows...

4. 4. There is no documented terrorist or national security emergency at the southern border...

5. There is no emergency related to violent crime at the southern border...

6. There is no human or drug trafficking emergency that can be addressed by a wall at the southern border...

7. This proclamation will only exacerbate the humanitarian concerns that do exist at the southern border...

8. Redirecting funds for the claimed "national emergency" will undermine U.S. national security and foreign policy interests...

9. The situation at the border does not require the use of the armed forces, and a wall is unnecessary to support the use of the armed forces...

10. There is no basis for circumventing the appropriations process with a declaration of a national emergency at the southern border...

11. For all of the foregoing reasons, in our professional opinion, ther is no factual basis for the declaration of a national emergency.... (Albright, et al, February 25, 2019, pp. 1-13, italics in the original.)

The president has used his executive powers to ostensibly circumvent Congress to build his border wall. Furthermore, when Trump tweets or holds campaign rallies, his followers hold on to the simulacrum of the wall representing in and of itself, security, while this is not the interpretation held by the U.S. government national and homeland security leaders; And herein 
follows an analysis of the security apparatus along the Mexico-U.S. border, following Foucault's and Agamben's conceptions in the context of Trump's emergency declaration.

\section{Security Apparatus I: Entering the Twilight (Border) Zone}

People dwelling along the border encounter the U.S. security apparatus as part of their everyday life in the borderlands (Staudt 2018). Within one hundred miles of the U.S. border and coast (Bump 2018), the U.S. Border Patrol may establish checkpoints to surveil movements of citizens and migrants through the statutory provisions of H.R.418 - the REAL ID Act of 2005. The law is originally designed and intended to "protect against terrorist entry" into the United States as:

To establish and rapidly implement regulations for state driver's license and identification document security standards, to prevent terrorists from abusing the asylum laws of the United States, to unify terrorism-related grounds for inadmissibility and removal, and to ensure expeditious construction of the San Diego border fence. (U.S. Congress $109^{\text {th, }}$ 2005)

While the law was ostensibly designed to prevent terrorists from entering the United States, the consequence of the law led to restrictions of movement by U.S. citizens living near the border. The American Civil Liberties Union (ACLU) (n.d.) notes that "Roughly two-thirds of the United States' population lives within the 100-mile zone - that is, within 100 miles of a U.S. land or coastal border. That is about 200 million people." Garrett and Storbeck (2011) made the case that these zones effectively erode the rights of U.S. citizens and put them into a category of homo sacer (based on Agamben 1995), those without rights who may be sacrified, although not into the other categories of homo sacer including migrants, refugees and potential terrorists who all have fewer legal protections.

The REAL ID Act of 2005 has the effect of statutorily depriving citizens, migrants, and refugees of their full measure of constitutional rights. The security apparatus is further enabled to behave in the same manner as an authoritarian state in the United States. Citizens living in this 
zone do not have the same rights as others. Population segmentation caused by the REAL ID Act has resulted in a bifurcation of classes of American citizenship — whether originally intended by Congress or not.

\section{The Security Apparatus II: Zero Tolerance, and the Family Detention/Separation of} Children from Parents Option

In October 2018, President Trump and the DHS were considering giving migrants and refugees the option of children staying with their parents or being separated-along the lines of the "former" Zero Tolerance policy that was implemented officially between April 6, 2018 and June 20, 2018. This policy resulted in a public relations disaster (Garrett 2018). Barrett (2018) noted that since the end of the Zero Tolerance policy that only 500 children out of 2,500 were reunited with their parents. Despite the problems created by the previous policy, the new arrangement would mean, "if parents and children are separated, parents will have a say, the officials emphasized. Under a 90-day pilot program, parents seeking asylum would be given a 'binary choice' to be detained with their children through the course of their immigration proceedings or to send their children to a shelter where they can be released to a sponsor" (Hesson 2018).

The number of migrant and refugee families had increased by 30 percent in September from the previous month. DHS spokeswoman Katie Waldman noted that "there is currently a crisis at our southern border as we encounter rising numbers of adults who enter the country illegally with children" (Hesson 2018). The pilot project would be difficult to implement because the DHS only maintains 3,326 family detention beds according to the U.S. Government Accountability Office (Hesson 2018). However successful DHS may believe its project is, the border wall is a 
beacon, and thus, a simulacrum, for human traffickers who have recently used market strategies

to move migrants and refugees from Guatemala as:

With the swelling arrest numbers [in 2019], calls for a border wall have intensified. But in recent weeks, large groups have crossed in areas near central El Paso, where tall, modern steel barriers are already in place. Wading through shallow stretches of the Rio Grande, the migrants reach U.S. soil and wait to be taken into custody on the narrow strip of no man's land between the river and the border fence" (Miroff 2019).

As the U.S. government agencies adjust to the larger numbers of migrants and refugees, the transnational criminal organizations have seized an opportunity to take economic advantage of the situation. However the new separation policy is implemented, the previous Zero Tolerance policy was implemented in the following manner (See Figure 2 below) ...

Figure 2. Zero Tolerance Policy Implemented by the Department of Justice and DHS, April 6, 2018: What It Means at the Southwest Border in Texas

1. The migrant family first attempts to cross the international checkpoint and make an asylum claim and is stopped at the international bridge....

2. The migrant family is forced to cross the Rio Grande....

Mexico:

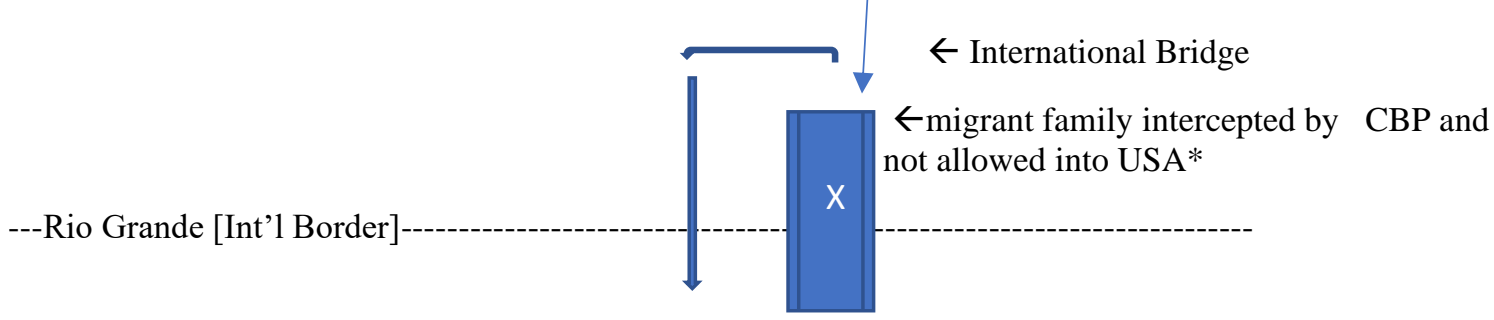




\section{$\mathbf{X}$ migrant family}

USA:

captured by

$$
\text { Border Patrol }
$$

* The migrant family, after being stopped by Custom Border Protection (CBP) agents, is forced to return into Mexico, thereby causing them to take the risk of crossing the Rio Grande - not at a checkpoint, resulting in a violation of 1911. 8 U.S.C. 1325 -- Unlawful entry, failure to depart, fleeing immigration checkpoints, marriage fraud, commercial enterprise fraud (civil penalty) (link: https://www.justice.gov/usam/criminalresource-manual-1911-8-usc-1325-unlawful-entry-failure-depart-fleeing-immigration)

3. The migrant family is then placed for approximately 48 hours in the hielera (ice box [or cooler] set at approximately 62 degrees Fahrenheit/17.8 degrees Celsius) and oftentimes the migrants are wet and cold. Afterwards, the migrant family unit is separated based on age and gender. This is where children are taken away from their parents.

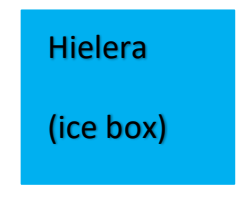

$$
\begin{aligned}
& \rightarrow \text { Child separation (options) } \rightarrow \text { US Department of Health and Human Services (HHS) } \\
& \qquad \begin{array}{r}
\rightarrow \text { Office of Refugee Resettlement (ORR) } \\
\quad \rightarrow \text { Southwest Key (or other private corporate vendors) }
\end{array}
\end{aligned}
$$

$\rightarrow$ Adults sent to the detention center $\rightarrow$ Perrera (dog kennel) $\rightarrow$ ICE takes over from CBP

4. Adult migrants are sent to federal courts as soon as possible (the goal is 48 hours) or to an Immigration Customs Enforcement (ICE) Detention Center. Migrants appear before a federal magistrate in numbers ranging from 20 to over 100 after having spent a few minutes with a court appointed defense attorney. They're generally charged with violations of the " 1325 " unlawful entry law unless there were other violations at the time of arrest. Eventually, they receive their sentence after pleading guilty, given credit for time served at the hierlera and perrera, then deported back to their country of origin (e.g., Honduras, El Salvador, Guatemala), oftentimes without their children. Children have lost contact with their parents and have to stay months until they're eventually sent back to their country of origin or sent to foster care designated by HHS and ORR.

Sources: Recreated by the author from the Texas American Civil Liberties Union Presentation June 13, 2018 at the Brownsville, Texas United Way Center, and based on Figure 1; first used in Garrett $(2018,101)$.

Notes (*): The migrant family, after being stopped by Custom Border Protection (CBP) agents, is forced to return to Mexico, thereby causing them to take the risk of crossing the Rio Grande - not at a checkpoint, resulting in a violation of 1911.8 U.S.C. 1325-Unlawful entry, failure to depart, fleeing immigration checkpoints, marriage fraud, commercial enterprise fraud (civil penalty). For more information see https://www.justice.gov/archives/usam/criminal-resource-manual-1911-8-usc-1325-unlawful-entryfailure-depart-fleeing-immigration)

Figure 2 demonstrates the Zero Tolerance policy implemented by DHS, CBP, and BP for the apprehension and detention of migrants and refugees coming from the Northern Triangle countries of Central America - and how it is essentially promulgating violations of U.S. and 
international law. Although the Trump administration and the security apparatus apparently officially ended the Zero Tolerance policy in June, the attempts at family separation as a matter of policy continues since there are still migrant and refugee children separated from their parents and the U.S. government has plans for further "voluntary" separation. By the end of 2018, nearly 15,000 migrant children were being held in mass shelter detention centers across the United States in total (Burke and Mendoza 2018). According to the Geneva, Switzerland-based nonprofit organization the Global Detention Project (n.d.),

The United States operates the world's largest immigration detention system. On any given day, the country has some 30,000 people in administrative immigration detention... [and in 2016] the combined budget of enforcement agencies was $\$ 19$ billion... with 200 facilities, including privately operated detention facilities, local jails, juvenile detention centres, field offices, and euphemistically named 'family residential centres.

Various public and for-profit institutions are involved in the policy of separation security apparatus including the Office of Refugee Resettlement, the U.S. Department of Health and Human Services, U.S. Federal District Court Magistrates working for the DHS on migration cases, as well as ICE and private vendor detention centers such as Southwest Key headquartered in Brownsville, Texas. Southwest Key houses about one third of the total number of migrant and refugee children under government contracts (Barber and Kulish 2019). As of June 2018, there were "87 child-care facilities and 15 transitional foster care programs" across the United States (Bogado 2018). All are complicit in activities that amount to violations of human rights laws such as the Convention Relating to the Status of Refugees and the associated Protocol Relating to the Status of Refugees (1968).

These international laws are abrogated,

despite the fact that [the U.S.] Constitution makes the rules in these treaties binding U.S. law, the Trump administration is treating asylum seekers as criminals. When the U.S. government prosecutes or imprisons these asylum seekers, it violates the rights protected in the two treaties that recognize the human right to seek asylum. (Davis 2018) 
As of February 2019, the Trump administration — via the state security apparatus - cannot find children of migrants they have separated as "the statement from the Office of Refugee Resettlement said at this point it would "destabilize the permanency of [the children's] existing home environment, and could be traumatic to the children to remove them from the sponsor homes where they were placed after separation" (The Week 2019). The family separation policy remains in effect even after the official declaration was made by the Trump administration that the Zero Tolerance policy is over on 20 June 2018. The New York Times notes,

Nearly nine months after the Trump administration officially rescinded its policy of separating migrant families who have illegally crossed the border, more than 200 migrant children have been taken from parents and other relatives and placed in institutional care, with some spending months in shelters and foster homes thousands of miles away from their parents. (Jordan and Dickerson 2019)

As of December 2019, the Trump administration has made "attempts to give ICE more access to the refugee program have generated significant opposition, because it potentially forces migrant parents to choose between reclaiming their children and risking arrest. Administration officials acknowledge the arrangement will instill fear among migrant parents, but they say it will deter families from having their children cross into the United States illegally" (Miroff 2019). The Zero Tolerance policy is still in effect and further attempts at refugee/migrant intimidation are being devised to be implemented by the state security apparatus.

\section{Security Apparatus III: The Wall as Architecture and US Troops on the Border}

President Donald J. Trump, while at a political rally held in Montana on November 3, 2018, stated "Barbed wire used properly can be a beautiful sight" (Hains 2018). Trump may have meant to say "concertina" wire while giving his speech at the Montana political rally. As shown previously, Senator Schumer and Representative Cuellar did not quite grasp the meaning of "wall" although they were sure that Trump was not supposed to be getting any, unless it was a levee wall. 
Barrier structures are apparently confusing and difficult for some elected officials to grasp the full meaning of the actual physical apparatuses in terms of how they are arrayed along the border. Rael $(2017,12)$ submits that there are eleven basic types of wall-type structures that are found on the Mexico-U.S. border: 1. Pedestrian; 2. Vehicular; 3. Bollard; 4. Hybrid (elements of both pedestrian and vehicular constructs); 5. Levee; 6. Natural; 7. Virtual; 8. Landing Mat; 9. Anti-ram; 10. Floating (sand dunes); and, 11. DYI (militia homemade barriers, primarily barbed wire). Since fall 2018, the Trump administration has added a new feature. As of March 2019, there are now approximately 700 miles of barriers, or walls, erected out of 1,954 miles of the Mexico-U.S. border. Active duty U.S. armed forces went to the border and placed military grade concertina wire around U.S. ports of entry and other sections of the border wall. Figures 3 and 4 are examples of this practice and show how the concertina wire was strapped to a bollard fence near $13^{\text {th }}$ and Levee streets by the Gateway International Bridge in Brownsville, Texas, in various configurations.

Figure 3. Concertina Wire Strapped to Bollard Fence, Brownsville, Texas, November 16, 2018

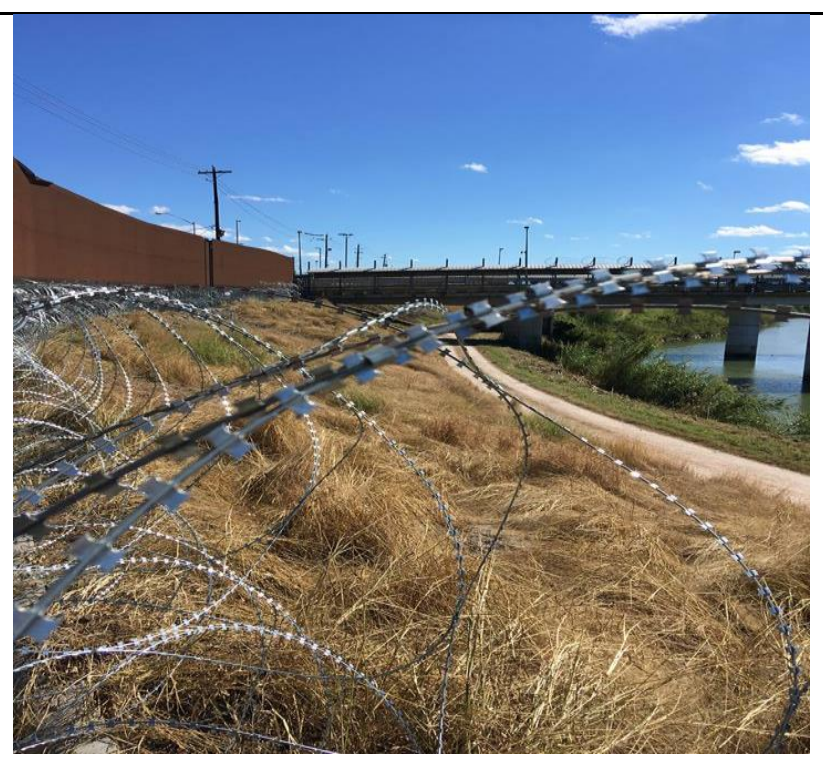

Source: Author Photo of Concertina Wire near Gateway International Bridge, Brownsville, Texas, November 16, 2018. 
Figure 4. Gateway International Bridge, Brownsville, Texas with Concertina Wire Configured on Top of the Port of Entry

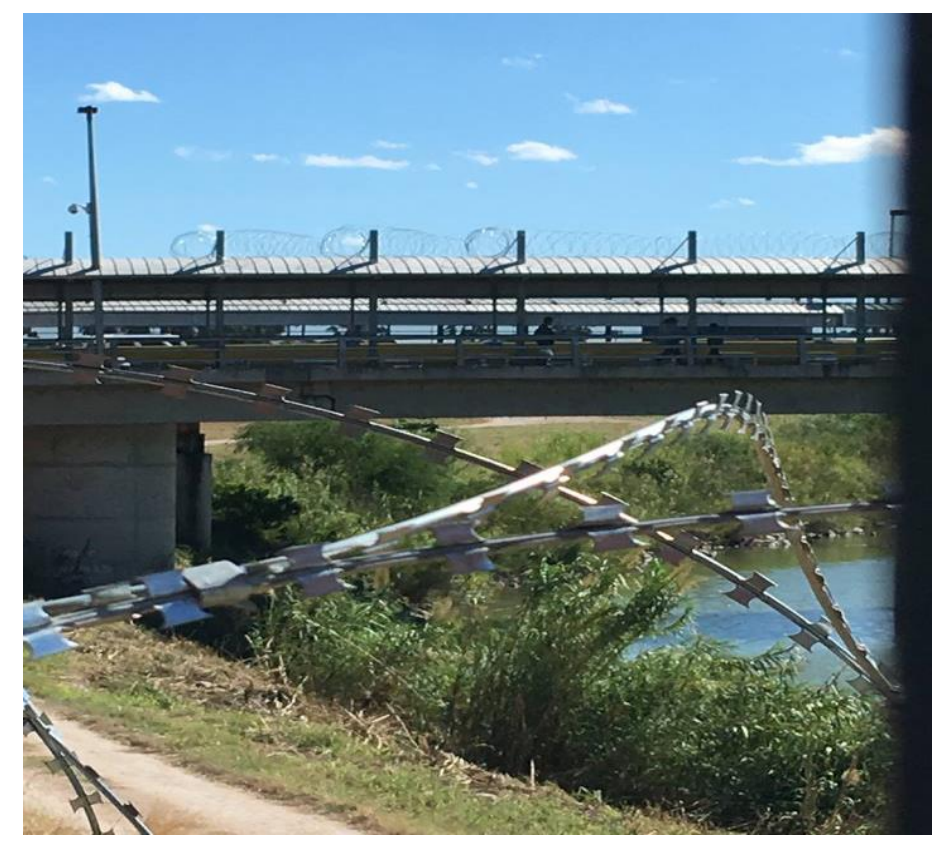

Source: Author Photo of Concertina Wire Configurations on Top of the Port of Entry Structure at the Gateway International Bridge, Brownsville, Texas, November 16, 2018.

With these two configurations, we see a modification of Rael's categorization of bollard wall construction with the concertina wire strapped to the apparatus as well as concertina wire strewn along the top of the bridge/port of entry structure.

On April 4, 2018, President Trump declared "to secure the border and make America safe, we need to deploy the National Guard...[which] will serve as an immediate deterrent while dramatically enhancing operational control of the U.S. border" (Ainsley and Jackson 2018). The escalation of troops continued as at least 5,200 active duty troops joined 2,000 National Guard troops in October 2018 while the Border Patrol union (National Border Patrol Council) head, Brandon Judd, called the National Guard deployment "a collosal waste of time," while simultaneously stating that the active duty soldiers were "duplicating, not adding to, [the] agents' 
efforts" (Galvan 2018). Due to U.S. law, National Guard and federal troops cannot have direct contact with migrants and may only help CBP and BP agents in support roles. U.S. military troops were deployed to lay "more than 150 miles (240 kilometers) of wire available to string up at strategic locations" along the border following CBP guidelines (Bryan 2018). U.S. taxpayers' costs for the "Operation Faithful Patriot" in late 2018 amount to $\$ 235$ million-\$132 million for active duty personnel and \$103 million for the National Guard. Beyond 2018 into 2019, the military presence costs are expected to run over $\$ 600$ million (Riotta 2019).

President Trump's movement of National Guard and active duty military personnelputting aside whether it was done for political reasons as in trying to affect the 2018 midterm elections - was to aid the Customs and Border Protection and U.S. Border Patrol agents on the southern border to prevent "caravans" of migrants and refugees from entering the country in an "illegal" manner. Symbolic actions such as the laying of concertina wire along the border where there are already walls send messages of fear and oppression to migrants and residents of border communities. Subsequent to the midterm election gambit, FY 2019 budget negotiations were breaking down with Congress for building Trump’s border wall. Trump asked Congress for \$5.7 billion and had used the request to threaten government shutdowns.

The symbolism of the wall strung with concertina wire was not lost on U.S. Rep. Raúl M. Grijalva, a Democrat representing the city of Nogales, Arizona, which had layers of wire strung heavily on the border wall that was not wanted by the people there. Congressman Grijalva stated that "the additional wire is nothing more than a spectacle by the Trump administration to reinforce his twisted narrative of rampant lawlessness at the border, [and]...Border residents know that this mischaracterization could not be further from the truth, and will not stand for the lies perpetrated by the Trump administration" (Rosenberg 2019). The militarization of the border continues with 
more wall coming as well as periodic visits by National Guard active duty federal troops who will likely string more concertina wire in the future if positioned along the border. The border wall simulacrum persists.

\section{Discussion, Summary, and Conclusion}

The increasing milarization of the border continues apace. Trump's campaign pledge to build a wall continues to meet resistance from border dwellers and from Congress to some degree as shown. Since Trump did not receive as much revenue to build his wall in the last two fiscal years as he wanted, Trump has made the wall a symbol, or simulacrum, of his determination to win, and keep, the political support from his constituents. The national emergency decree by Trump was voted down by the Democratic-controlled House of Representatives and the Republican-controlled Senate. Trump and the Congress continue to engage in an attempt to control whether Trump's long-promised wall extending most of the 1,954 miles of southern border will be built as:

The Republican-controlled Senate approved a resolution to terminate President Trump's national emergency declaration at the U.S.-Mexico border, putting Congress on a path to its first veto confrontation with the Trump administration...Shortly after the vote, President Trump tweeted, 'VETO!' Neither chamber mustered the two-thirds support required to override a presidential veto. (Davis 2019)

The struggle between the president and Congress continues to play out with regard to the constitutionality of the Trump's border wall-driven declaration of a national emergency and the the strengthening of the security apparatus at the expense of republican governance. Beyond the emergency declaration funding that Trump wants for the wall, he is requesting $\$ 8.6$ billion for fiscal year 2020 to build an additional wall (Paletta et al. 2019), which will certainly lead to further conflict in a presidential election year. The continued state of exception will lead to further curbs on citizens' and migrants' civil rights. 
Border zones will continue to exist due to the provisions of the REAL ID law of 2005 and provisions of the Secure Fence Act of 2006 and the current implementation of it by Congress and the president. Unless changes are made to the law, or the elimination of it, citizens in the United States will continue to live in restrictive areas and will find themselves limited in terms of having their full measure of civil liberties.

Detention centers and the continuation of Trump's Zero Tolerance policy usurp U.S. laws designed to protect migrants and refugees - and their children entering the United States. The security apparatus machinery is still in full force despite the false claims by the Trump administration stating that the policy was no longer in effect when challenged by Congress and the courts.

The Trump administration is clearly moving in an dictatorial/authoritarian direction in terms of its policy actions that are exemplified by the subjectivity of migrants and border zone dwellers. While not exclusive to the current governing regime, continued expansion of the erosion of constitutional rights of the people results in a prolegomena to an authoritarian state if the United States follows the same path accentuated by recent policy actions engendered by President Trump's administration and his congressional allies. U.S. migration policy and the concomitant border security apparatus are transparent indicators of the ongoing movement toward an antidemocratic governmental system. The border wall simulacrum is symbolic of the divisive and interpretive imagery used by Trump as a roadmap to maintain power and control over the security apparatus, in this case at the expense of American democracy.

\section{About the Author}

TERRY GARRETT (PhD University of Oklahoma) is professor of political science at UTRGV. Expertise areas include international relations, comparative politics and public 
administration/policy. A student of phenomenology via Husserl and Merleau-Ponty, Terry's work

follows Marcuse and the Frankfurt School into critical theory. His recent works reflect French

Situationist and post-modern, post-structuralist theorists to explain how philosophy and theory explains reality. Terry is an associate editor for the International Journal of Social Economics (IJSE) and has published in academic journals including IJSE, the American Review of Public Administration, Administration and Society, Administrative Theory and Praxis, among numerous others.

\section{References}

Agamben, Giorgio. 1995. Homo Sacer: Sovereign Power and Bare Life. Stanford, CA: Stanford University Press. 2005. State of Exception. Chicago, IL: University of Chicago Press. 2009. What is an Apparatus? Stanford, CA: Stanford University Press.

Ainsley, Julia, and Hallie Jackson. 2018. "Trump Sending National Guard Troops to Mexico Border, but They Won't Have Contact with Immigrants." NBC News No. 04/2018. Accessed on February 11, 2020. Available online at https://www.nbcnews.com/politics/immigration/trump-sending-troopsmexico-border-they-won-t-have-contact-n862736

Albright, Madeleine, Jeremy B. Bash, John B. Bellinger III, Daniel Benjamin, Antony Blinken, John O. Brennan, R. Nicholas Burns, Johnnie Carson, James Clapper, David S. Cohen, Eliot A. Cohen, Ryan Crocker, Thomas Donilon, Jen Easterly, Nancy Ely-Raphel, Daniel P. Erikson, John D. Feeley, Daniel F. Feldman, Jonathan Finer, Jendayi Frazer, Suzy George, Phil Gordon, Chuck Hagel, Avril D. Haines, Luke Hartig, Heather A. Higginbottom, Roberta Jacobson, Gil Kerlikowske, John F. Kerry, Prem Kumar, John E. McLaughlin, Lisa O. Monaco, Janet Napolitano, James D. Nealon, James C. O'Brien, Matthew G. Olsen, Leon E. Panetta, Anne W. Patterson, Thomas R. Pickering, Amy Pope, Samantha J. Power, Jeffrey Prescott, Nicholas Rasmussen, Alan Charles Raul, Dan Restrepo, Susan E. Rice, Anne C. Richard, Eric P. Schwartz, Andrew J. Shapiro, Wendy R. Sherman, Vikram Singh, Dana Shell Smith, Jeffrey H. Smith, Jake Sullivan, Strobe Talbott, Linda Thomas-Greenfield, Arturo A. Valenzuela. 2019. "Read the Letter: 58 Former National Security Officials Protest Trump's Emergency Declaration (Joint Declaration of Former United States Government Officials). The Washington Post No. 25/2019 . Accessed on February 11,2020. Available online at https://www.washingtonpost.com/read-the-letter-58-former-nationalsecurity-officials-protest-trump-s-emergency-declaration/f5bbafbb-eabd-41d9-8cab740fd515e8a7_note.html?utm_term=.757aa9a2dc16

American Civil Liberties Union. n.d. "The Constitution in the 100-mile Border Zone." Accessed on February 11, 2020. Available online at https://www.aclu.org/other/constitution-100-mile-borderzone

Andreas, Peter. 2009. Border Games: Policing the U.S.-Mexico Divide, $2^{\text {nd }}$ Edition. Ithaca, NY: Cornell University Press. 
Barber, Kim, and Nicholas Kulish. 2019. Inquiry into Migrant Shelters poses Dilemma: What happens to the Children? The New York Times No.05/2019. Accessed on February 11, 2020. Available online at https://www.nytimes.com/2019/01/05/us/southwest-key-migrant-shelters.html

Barrett, Devlin. 29 June 2018. Trump Administration may detain Migrant Families Longer than Previously Allowed. The Washington Post. Accessed on February 11, 2020. Available online at https://www.washingtonpost.com/world/national-security/trump-administration-plans-to-detainmigrant-families-for-months/2018/06/29/f9ffecb6-7bf7-11e8-93cc-

6d3beccdd7a3_story.html?utm_term=.50ffbf74bb76

Baudrillard, Jean. 2006. Simulacra and Simulation. Ann Arbor, MI: University of Michigan Press.

Berger, Peter, and Thomas Luckmann. 1980. The Social Construction of Reality. New York, NY: Irvington Publishers.

Blake, Aaron. 2019. "Trump's National Emergency Press Conference, Annotated." The Washington Post No. 15/2019. Accessed on February 11, 2020. Available online at https://www.washingtonpost.com/politics/2019/02/15/trumps-bewildering-national-emergencypress-conference-annotated/?utm_term=.0fe84863f01a

Bogado, Aura. 2018. "Here's a Map of Shelters where Immigrant Children have been Housed." Reveal News No. 26/2018. Accessed on February 11, 2020. Available online at https://www.revealnews.org/article/heres-a-map-of-shelters-where-immigrant-children-havebeen-housed/

Brown, Wendy. 2010. Walled States, Waning Sovereignty. New York, NY: Zone Books.

Bryan, Susan Montoya. 2018. "Razor Wire is Most Visible Result of \$210M Troop Deployment to the USMexico Border." Military Times No. 21/2018. Accessed on February 11, 2020. Available online at https://www.militarytimes.com/news/pentagon-congress/2018/11/22/razor-wire-is-most-visibleresult-of-210m-deployment/

Bump, Philip. 2018. "Can the Border Patrol ask for your Papers? This Tool Shows if You're in the 'Border Zone." The Washington Post No. 22/2018. Accessed on February 11, 2020. Available online at https://www.washingtonpost.com/news/politics/wp/2018/06/22/can-the-border-patrol-ask-foryour-papers-this-tool-shows-if-youre-in-the-border-zone/?utm_term=.c3e55e4ab9bb

Burke, Garance, and Martha Mendoza. 2018. "Nearly 15,000 Migrant Children held in Mass Shelters, AP Investigation Finds." Tennessean No. 19/2018. Accessed on February 11, 2020. Available online at https://www.tennessean.com/story/news/investigations/2018/12/19/migrant-kids-separatedheld-mass-shelters/2362032002/

Davis, Jeffrey. 2018. "U.S. 'Zero-Tolerance' Immigration Policy Still Violating Fundamental Human Rights Laws." United Press International No. 27/2018. Accessed on February 11, 2020. Available online at https://www.upi.com/Top_News/Voices/2018/06/27/US-zero-tolerance-immigration-policystill-violating-fundamental-human-rights-laws/2171530104203/

Davis, Susan. 2019. “Trump Vows Veto after Congress Blocks His Order to Build Border Wall.” National Public Radio. No. 14/2019. Accessed on February 11, 2020. Available online at https://www.npr.org/2019/03/14/703379399/congress-overturns-trumps-national-emergencydeclaration-to-build-thewall?utm_source=facebook.com\&utm_medium =social\&utm_campaign=npr\&utm_term=nprnews \&utm_content=20190314\&fbclid=IwAR1_YK4fF6xtW3PWnfyIk4keUOzlkTSliwyyc75o3U3ZZ UOHIvqUJVUiZPo

Edgerton, Anna, Erik Wasson, and Laura Litvan. 2019. "Trump's Border Emergency sets up Clash over Presidential Powers." Bloomberg No. 26/2019. Accessed on February 11, 2020. Available online 
at https://www.bloomberg.com/news/articles/2019-02-26/trump-s-border-emergency-sets-upclash-over-presidential-powers

Ferman, Mitchell, and Lorenzo Zazueta-Castro. 2017. "A Tale of Two Walls: Levee, Bollard Construction Creates Confusion even among Top U.S. Lawmakers." The Monitor No. 30/2017. Accessed on February 11, 2020. Available online at https://www.themonitor.com/2017/09/30/a-tale-of-twowalls-levee-bollard-construction-creates-confusion-even-among-top-us-lawmakers/

Finnegan, Michael. 2016. "'It's going to be a Big, Fat, Beautiful Wall!': Trump's Words Make His California Climb an Even Steeper Trek.” Los Angeles Times No. 03/2016. Accessed on February 11, 2020. Available online at https://www.latimes.com/politics/la-na-pol-trump-california-campaign20160602-snap-story.html

Foucault, Michel. 1970. The Order of Things: An Archaeology of the Human Sciences. New York, NY: Random House.

1980. Power/Knowledge: Selected Interviews and other Writings, 1972-1977. New York, NY: Pantheon.

. 2008. The Birth of Biopolitics. New York, NY: Palgrave MacMillan.

Frost, Tom. 2019. “The Dispositif Between Foucault and Agamben.” Law, Culture and the Humanities 15 (1): 151-171. Accessed on February 11, 2020. Available online at https://doi.org/10.1177/1743872115571697

Galvan, Astrid. 2018. "This Federal Law Limits What U.S. Troops Deployed at the Border Can Do." Military Times No. 30/2018. Accessed on February 11, 2020. Available online at https://www.militarytimes.com/news/your-military/2018/10/31/federal-law-limits-what-ustroops-deployed-at-the-border-can-do/

Garrett, Terence M. 2018. "An Analysis of U.S. Custom and Border Protection's Tripartite Mexico Border Security Policy.” Annales: Ethics in Economic Life 21 (4): 89-111. Accessed on February 11, 2020. Available online at https://doi.org/10.18778/1899-2226.21.4.07

Garrett, Terence M., and James E. Storbeck. 2011. "The DHS Border Fence in the Rio Grande Valley: Semiotics, Space, and Subjectivity." Administrative Theory and Praxis 33 (4): 530-548. Accessed on February 11, 2020. Available online at https://doi.org/10.2753/ATP1084-1806330402

Global Detention Project. n.d. "United States Immigration Detention." Global Detention Project. Accessed on February 11, 2020. Available online at https://www.globaldetentionproject.org/countries/americas/united-states

Hains, Tim. 2018. Trump on Border Wall: Barbed Wire used Properly can be a Beautiful Sight. Real Clear Politics No. 05/2018. Accessed on February 11, 2020. Available online at https://www.realclearpolitics.com/video/2018/11/05/trump_on_border_wall_barbed_wire_used_p roperly_can_be_a_beautiful_sight.html

Hesson, Ted. 2018. "Trump Administration Considers Family Separation Option as Border Arrests Soar." Politico No. 12/2018. Accessed on February 11, 2020. Available online at https://www.politico.com/story/2018/10/12/trump-administration-family-separations-return846971

Hirschfeld Davis, Julie, and Peter Baker. 2019. "How the Border Wall is Boxing Trump in." The New York Times No. 05/2019. Accessed on February 11, 2020. Available online at https://www.nytimes.com/2019/01/05/us/politics/donald-trump-border-wall.html 
Jordan, Miriam, and Caitlin Dickerson. 2019. "U.S. Continues to Separate Migrant Families Despite Rollback of Policy." The New York Times No. 09/2019. Accessed on February 11, 2020. Available online at https://www.nytimes.com/2019/03/09/us/migrant-family-separationsborder.html?emc=edit_ctb_20190314\&nl=crossing-the-border\&nlid=7329091720190314\&te=1

Mark, Michelle. 2019. “'I Don't Know Who's Telling the President this is a Good Idea': Former ICE Director Says Trump's Wall Makes 'So LIttle Sense."” Business Insider No. 22/2019. Accessed on February 11, 2020. Available online at https://www.thisisinsider.com/former-ice-director-sarah-saldanasays-trumps-wall-doesnt-stop-true-threat-2019-1

.2019. "A Simple Technology could secure the Border for a Fraction of the Cost of a Wall-But No One's Talking about It. Business Insider No. 02/2019. Accessed on February 11, 2020. Available online at https://www.businessinsider.com/fiber-optic-sensing-technology-vs-borderwall-2019-

2?fbclid=IwAR3eaG4DQprP9xSqAOAlqktlE6YL1gcV0XNmvay7pjy1H6csDpLCZtXKDFQ

Miroff, Nick. 2019. “'The Conveyor Belt:' U.S. Officials say Massive Smuggling Effort is Speeding Immigrants to - and Across - the Southern Border." The Washington Post No. 15/2019. Accessed on February 11, 2020. Available online at https://www.washingtonpost.com/national/theconveyor-belt-us-officials-say-massive-smuggling-effort-is-speeding-immigrants-to--and-across-the-southern-border/2019/03/15/940bf860-4022-11e9-a0d3-

1210e58a94cf_story.html?fbclid=IwAR3bVzLA0mGdTzUnzvehbMgqAfSIUsnOuSzPDYRyJzi

HHUxlpBBxAbhpZps\&utm_term=.7f941c561c78\&wpisrc=al_news_alert-world--alertnational\&wpmk=1

Miroff, Nick. 2019. "Under Secret Stephen Miller Plan, ICE to use Data on Migrant Children to Expand Deportation Efforts." The Washington Post No. 20/2019. Accessed on February 11, 2020. Available online at https://www.washingtonpost.com/immigration/under-secret-stephen-millerplan-ice-to-use-data-on-migrant-children-to-expand-deportation-efforts/2019/12/20/36975b3422a8-11ea-bed5-

880264cc91a9_story.html?utm_campaign=post_most\&utm_medium=Email\&utm_source=Newsl etter\&wpisrc=nl_most\&wpmm=1

Noe, Lance J. 2002. "9-11 as Nostalgia: Implications for Public Administration Theory and Practice." Administrative Theory and Praxis 24 (3): 572-606. Accessed on February 11, 2020. Available online at https://www.jstor.org/stable/25611601

Paletta, Damien, Mike Debonis, and John Wagner. 2019. “Trump Declares National Emergency on Southern Border in Bid to Build Wall." The Washington Post No. 15/2019. Accessed on February 11, 2020. Available online at https://www.washingtonpost.com/politics/trumps-border-emergencythe-president-plans-a-10-am-announcement-in-the-rose-garden/2019/02/15/f0310e62-3110-11e986ab-5d02109aeb01_story.html?utm_term=.6309218499ac

Paletta, Damien, Erica Werner, and Jeff Stein. 2019. “Trump Seeks \$4.7 Trillion Budget with Domestic Cuts, \$8.6 Billion in Wall Funding.” The Washington Post No. 11/2019. Accessed on February 11, 2020. Available online at https://www.washingtonpost.com/business/economy/trump-proposes47-trillion-budget-with-domestic-cuts-86-billion-in-wall-funding/2019/03/11/de11 cfa4-43fe11e9-90f0-0ccfeec87a61_story.html?utm_term=.72bf32d8440b

Rael, Ronald. 2017. Borderwall as Architecture: A Manifesto for the U.S.-Mexico Boundary. Berkeley, CA: University of California Press.

Riotta, Chris. 2019. "Trump Orders 'Several Thousand' More Troops to US-Mexico Border, Costing Taxpayers Over $\$ 600 \mathrm{~m}$. The Independent No. 30/2019. Accessed on February 11, 2020. Available 
online at https://www.independent.co.uk/news/world/americas/us-politics/trump-border-troopsus-mexico-wall-cost-migration-immigrants-daca-shutdown-taxpayers-a 8754406.html

Rosenberg, Eli. 2019. “Trump's Troop Deployment Strung 'Lethal' Razor Wire on the Border. This City Has Had Enough." The Washington Post No. 07/2019. Accessed on February 11, 2020. Available online at https://www.washingtonpost.com/nation/2019/02/07/trumps-troop-deployment-strunglethal-razor-wire-border-this-city-has-had-enough/?utm_term $=.543 \mathrm{cb} 906 \mathrm{c} 371$

Ross, Brian, Brian Epstein, and Paul Blake. 2017. "Retiring Border Chief Calls Trump's Wall a Waste of Time, Money." ABC News No. 23/2017. Accessed on February 11, 2020. Available online at https://abcnews.go.com/Politics/trumps-border-wall-waste-time-money-retiringborder/story?id=44978156

Ryman, Anne, Dennis Wagner, Rob O'Dell, and Kirsten Crow. 2017. "The Wall." USA Today. Accessed on February 11, 2020. Available online at https://www.usatoday.com/border-wall/

Schutz, Alfred. 1967. The Phenomenology of the Social World. Evanston, IL: Northwestern University Press.

Staudt, Kathleen. 2018. Border Politics in a Global Era: Comparative Perspectives. Lanham, MD: Rowman and Littlefield.

The Week. 2019. "Trump Administration says Reuniting Separated Migrant Children with Family may be Impossible." The Week No. 03/2019. Accessed on February 11, 2020. Available online at https://theweek.com/speedreads/821502/trump-administration-says-reuniting-separated-migrantchildren-family-may-impossible

Trump, Donald J. 2019. Twitter No. 24/2019. Accessed on February 11, 2020. Available online at https://twitter.com/realDonaldTrump/status/1088470495312400384

United States Congress $\left(109^{\text {th }}\right)$. 2005. "H.R.418-REAL ID Act of 2005." United States Congress. Accessed on February 11, 2020. Available online at https://www.congress.gov/bill/109thcongress/house-bill/418/text 